\title{
Susceptibility of captive adult winter-run Chinook salmon Oncorhynchus tshawytscha to waterborne exposures with infectious hematopoietic necrosis virus (IHNV)
}

\author{
K. D. Arkush ${ }^{1,2, *}$, H. L. Mendonca ${ }^{1}$, A. M. McBride ${ }^{1}$, R. P. Hedrick ${ }^{2}$ \\ ${ }^{1}$ Bodega Marine Laboratory, University of California at Davis, PO Box 247, Bodega Bay, California 94923, USA \\ ${ }^{2}$ Department of Medicine and Epidemiology, School of Veterinary Medicine, University of California at Davis, \\ Davis, California 95616, USA
}

\begin{abstract}
Sexually mature female Chinook salmon Oncorhynchus tshawytscha with no prior history of exposure to infectious hematopoietic necrosis virus (IHNV) were susceptible to experimental infection induced by additions of virus to the water. The resulting infections resembled those observed among naturally infected hatchery and wild populations of Chinook salmon. Virus was detected as early as $4 \mathrm{~d}$ post-exposure (p.e.) and subsequently in all virus-exposed fish that died or that were examined at $14 \mathrm{~d}$ p.e. when the study was terminated. The greatest concentrations of virus, up to $10^{8}$ plaque-forming units (pfu) $\mathrm{ml}^{-1}$, were found in the ovarian fluid at 13 to $14 \mathrm{~d}$ p.e., but the virus was also found in high concentrations in the gill, kidney/spleen and plasma. In contrast, the virus was not recovered from unexposed control adult salmon that died or were sampled at the end of the study. Despite detecting concentrations of IHNV in excess of $10^{7} \mathrm{pfu} \mathrm{g}^{-1}$ of tissue, no specific microscopic lesions were found in IHNV-exposed compared to unexposed control salmon. The results of this initial study suggest that virus in the spawning environment, either from adult salmon or other sources, may contribute to its rapid spread among adult Chinook salmon, thereby considerably increasing the prevalence of IHNV infection in both wild and hatchery populations of adult Chinook salmon.
\end{abstract}

KEY WORDS: IHNV · Spawning Chinook salmon

Resale or republication not permitted without written consent of the publisher

\section{INTRODUCTION}

Infectious hematopoietic necrosis virus (IHNV) continues to have major impacts on hatchery production of both salmon and trout, either directly by causing significant mortality in young fish, or indirectly by inducing deformities that increase the processing costs of rainbow trout (Busch 1983, LaPatra et al. 2001). Insights into the biological (LaPatra 1998) and genetic properties of IHNV have been achieved by $50 \mathrm{yr}$ of research, including recent comprehensive molecular epidemiological investigations of isolates throughout the original geographic range of the virus (Kurath et al. 2003). Despite these advances, some very basic fea- tures of the virus life cycle remain unresolved. Perhaps the greatest among these is the nature of the relationship between the virus and the host that survives initial infection.

Virus epidemics due to IHNV are most often observed among young salmonids, generally within the first 1-2 mo post-hatch. During this acute phase of the infection, the virus is readily isolated from internal organs, the skin, mucus, feces and urine (Wolf 1988, LaPatra et al. 1989). The virus can also be recovered from fish surviving infections shortly after their recovery from the acute phase, but rarely thereafter (Amend 1975, Drolet et al. 1995, Kim et al. 1999). The virus becomes evident again in the tissues of sexually mature 
salmonids (Amend 1975, Mulcahy et al. 1982). Epidemics among yearling or older hatchery-reared and wild salmonids have rarely been observed (Williams \& Amend 1976, Burke \& Grischkowsky 1984, Traxler 1986, Busch 1983) and this may reflect an increasing resistance associated with both greater size and age of the fish (LaPatra et al. 1990, LaPatra 1998).

At present, the most frequently observed IHNV infections are those recorded among sexually mature Pacific salmon or rainbow trout Oncorhynchus mykiss within the original geographic range of the virus (Pilcher \& Fryer 1980). Virus in mature fishes is perhaps reactivated from persistent or latent infections or, alternatively, results from virus transmission to or between adult salmonids. Evidence for both transmission pathways has been found for rainbow trout (Amend 1975) and sockeye salmon O. nerka (Mulcahy et al. 1982, 1983a,b, Mulcahy \& Pascho 1985). Based on transmission of the virus to Atlantic salmon Salmo salar by cohabitation with Chinook salmon $O$. tshawytscha previously exposed to IHNV, St-Hilaire et al. (2001) concluded that a carrier state also exists in the latter species. The duration of such a carrier state in Chinook salmon is unclear, and direct correlations between virus epidemics in young fish and increased virus prevalence in sexually mature adults returning to the hatchery have been inconclusive (Engelking et al. 1994). Therefore, it remains uncertain whether a lifelong carrier state develops in fish surviving initial infections with IHNV.

Experiments with rainbow trout (LaPatra et al. 1993) and sockeye salmon (Yamamoto et al. 1988) have demonstrated that adult salmonids can become infected with virus from exogenous sources. The susceptibility of adults and the increasing prevalence of IHNV infections in fish returning as adults to the hatchery suggest that virus initially released from adults arriving early in the salmon-run is the source of infection for later adult arrivals (Mulcahy et al. 1982). A similar transmission mechanism may operate in adult Chinook salmon returning to hatcheries in California, since the prevalence of virus infection is generally higher in later arrivals (Wingfield \& Chan 1970, R. P. Hedrick unpubl. data).

Chinook salmon returning to certain hatcheries in the Sacramento River basin of Northern California are known to be infected with IHNV, and epidemics due to the virus in juvenile salmon occur sporadically (Ross et al. 1960, Parisot \& Pelnar 1962, Wingfield \& Chan 1970, Mulcahy et al. 1983a, Free \& Foott 1998, R. P. Hedrick unpubl. data). The virus is usually not detected in the first adults returning to these hatcheries. However, as the run progresses, virus detection increases and, in some adult populations of Chinook and sockeye salmon, prevalence reaches $100 \%$ (Mulcahy et al. 1983a, Mulcahy \& Pascho 1985). Whether this increased prevalence is due to adult-to-adult transmission of the virus or to a reactivation of persistent or latent virus in the later arrivals is not known. Since IHNV can be prevalent among juveniles in hatcheries where IHNV epidemics occur, infected fish or those that have survived infection may be released and begin their seaward migration. Attempts to correlate the release of infected juvenile Chinook with IHNV prevalence in the same populations when they return as sexually mature adults have been unsuccessful (Engelking et al. 1994).

At least 2 explanations for the life cycle of the virus have been proposed to explain the apparent disappearance of the virus following infection of juveniles and its reappearance in sexually mature adults. The first hypothesis proposes that some fraction of young salmonids surviving IHNV infection develop persistent or latent infections that are reactivated at sexual maturity, perhaps due to a weakened immune response accompanying the stress of reproduction in nonsemelparous species (e.g. rainbow or steelhead trout) and/or the physiological processes in semelparous salmonids that precede death (Amend 1975, Drolet et al. 1995, Kim et al. 1999). A second hypothesis is that virus infections in juveniles are cleared from surviving fish by a combination of nonspecific and specific immune responses (LaPatra et al. 2001) that is no longer effective among sexually mature adults, thus providing a large naïve population susceptible to re-infection (Mulcahy et al. 1982). The latter theory assumes that sexually mature salmonids come in contact with the virus among fishes or other animal populations in the freshwater environment.

Overlap between migrating salmonids or infections among landlocked or resident salmonids may be 1 potential source of infection in both naturally produced and hatchery-reared adult salmon. For example, sufficient overlap of the spring, winter and fall Chinook salmon runs has meant that spawning salmon could be found throughout the year in the Sacramento River (Healy 1991), with the subsequent potential for transmission of IHNV between adults and from adults to juveniles. The presence of other organisms that could harbor and maintain the virus in the salmon spawning habitat has been proposed. The virus has been found among leeches in the spawning habitat of sockeye salmon, and fish-to-fish transmission by leeches has been demonstrated (Mulcahy et al. 1983b, Yamamoto et al. 1988). Also, IHNV is known to replicate in cell lines derived from insects that could serve as potential reservoir hosts in the freshwater environment (Bussereau et al. 1975, Scott et al. 1980). It is likely that both the recrudescence of persistent infections in fish surviving IHNV infection as juveniles and the rapid 
spread of the virus among adult salmonid populations via some alternate source in the spawning habitat are involved in the life cycle of IHNV. Indirect evidence for both mechanisms has been in laboratory trials and during field observations (Amend 1975, Mulcahy et al. 1982, Mulcahy \& Pascho 1985, Drolet et al. 1995, Kim et al. 1999).

We studied the susceptibility of adult Chinook salmon to IHNV infection using surplus adults from a hatchery-reared restoration stock. These salmon had been reared in fresh water and seawater free of the virus throughout their life, and thus served as known uninfected stocks for the infectivity trials. The response of these adult salmon following waterborne exposure to IHNV is described.

\section{MATERIALS AND METHODS}

The fish used in this experiment were female winterrun Chinook salmon that had been reared entirely in captivity as part of a broodstock program for this federally endangered species. For experimental purposes, 12 mature females (broodyears 1998 and 1999) that had not spawned in time to be integrated into the supplementation program were available. The fish were divided into 2 groups of 6 fish each and held in 6501 circular tanks supplied with fresh well-water at 11.4 to $12.4^{\circ} \mathrm{C}$. As these fish were in the final stages of sexual maturity they were not fed during the study period. A strain of IHNV (CDFG02-8-5) originally isolated from adult steelhead at the Feather River hatchery, Oroville, California in 2002, was propagated in the Chinook salmon embryo cell line CHSE-214 as previously described by Arkush et al. (1989). The water level in both tanks was reduced to a final volume of 2801 . One tank received an addition of $112.4 \mathrm{ml}$ of cell-culture supernatant containing $7.4 \times 10^{8}$ $\mathrm{TCID}_{50} \mathrm{ml}^{-1}$ (50\% tissue culture infective dose) (dose of $3.5 \times 10^{5} \mathrm{TCID}_{50} \mathrm{ml}^{-1}$ ). Aeration was supplied for a static exposure period of $5 \mathrm{~h}$ and then water flow was resumed to both tanks. All dead fish and fish sampled at specific time points were examined by standard necropsy procedures and tissue samples were processed for detection of IHNV as described by Thoesen (1994), except for modifications detailed below. On Days 13 and 14 post-exposure, surviving fish in both the virusexposed and unexposed groups were euthanized with an overdose of methane tricaine sulfonate (MS-222, Argent Chemical Laboratories). Blood was collected from the caudal vein, centrifuged at $444 \times g$ for $10 \mathrm{~min}$, and the plasma retained. Ovarian fluid was collected by insertion of a pipette into a small incision in the abdominal wall.
Both plasma and ovarian fluid were mixed in equal volumes of an antibiotic solution. Gill tissue was removed and macerated in minimal essential medium. Half of the homogenate was passed through a $0.22 \mu \mathrm{m}$ cellulose acetate syringe filter, while the remainder was not filtered but was treated only with antibiotics. Kidney and spleen tissues from each fish were pooled (total of 0.5 to $1.0 \mathrm{~g}$ ) for virus analyses. Virus titers were determined either by TCID $_{50}$ (for Virus-exposed Fish 1 and 2) or plaque assay (all other fish) on the epithelioma papillosum cyprini (EPC) cell line. Portions of the kidney, liver, spleen, heart, distal intestine, and gill were collected from 4 fish in each of the exposed and control groups and placed in Davidson's fixative. After $24 \mathrm{~h}$, the tissue samples were transferred to $70 \%$ ethanol. Histological specimens were processed for standard paraffin embedding, sectioning, and staining with hematoxylin and eosin (Humason 1979).

\section{RESULTS}

Prior to beginning the experiment, one of the salmon died and could not be replaced, so 5 fish were used in the control group. During the experimental period, 4 fish died: 3 exposed fish (at 4, 8, and 14 d p.e.) and 1 control fish (at $8 \mathrm{~d}$ p.e.). IHNV was recovered from all of the experimentally exposed fish, but was not detected in the control group (Table 1). Concentrations of virus varied between fishes and between tissues or fluids collected from any one individual, with the highest values detected in the ovarian fluid. Blood could

Table 1. Oncorhynchus tshawytscha. Concentrations (pfu g ${ }^{-1}$ ) of infectious hematopoietic necrosis virus (IHNV) in tissues of winterrun Chinook salmon following experimental waterborne exposures to $3.5 \times 10^{5} \mathrm{TCID}_{50}$ IHNV ml ${ }^{-1}$ or held under the same conditions without addition of virus to tank water (Control). Days p.e.: days post-exposure; nd: no virus detected

\begin{tabular}{|c|c|c|c|c|c|}
\hline Fish & $\begin{array}{l}\text { Days } \\
\text { p.e. }\end{array}$ & $\begin{array}{c}\text { Kidney + } \\
\text { spleen }\end{array}$ & $\begin{array}{l}\text { Ovarian } \\
\text { fluid }\end{array}$ & $\begin{array}{c}\text { Gill } \\
\text { (filtered) }\end{array}$ & Plasma \\
\hline \multicolumn{6}{|c|}{ Exposed } \\
\hline $1^{\mathrm{a}}$ & 4 & $5.00 \times 10^{2}$ & $1.58 \times 10^{3}$ & $5.00 \times 10^{5}$ & - \\
\hline $2^{\mathrm{a}}$ & 8 & $1.58 \times 10^{3}$ & $1.58 \times 10^{3}$ & $1.58 \times 10^{5}$ & - \\
\hline 3 & 13 & $8.25 \times 10^{4}$ & $4.88 \times 10^{6}$ & $1.78 \times 10^{7}$ & $3.00 \times 10^{4}$ \\
\hline 4 & 13 & $4.00 \times 10^{5}$ & $3.65 \times 10^{8}$ & $4.50 \times 10^{4}$ & $2.13 \times 10^{5}$ \\
\hline 5 & 14 & $4.68 \times 10^{5}$ & $2.50 \times 10^{8}$ & $8.75 \times 10^{4}$ & $1.25 \times 10^{4}$ \\
\hline 6 & 14 & $1.50 \times 10^{4}$ & $2.35 \times 10^{6}$ & $1.25 \times 10^{4}$ & $4.75 \times 10^{4}$ \\
\hline \multicolumn{6}{|c|}{ Control } \\
\hline 1 & 8 & nd & nd & nd & nd \\
\hline 2 & 13 & nd & nd & nd & nd \\
\hline 3 & 13 & nd & nd & nd & nd \\
\hline 4 & 14 & nd & nd & nd & nd \\
\hline 5 & 14 & nd & nd & nd & nd \\
\hline \multicolumn{6}{|c|}{${ }^{\mathrm{a}}$ Viral concentrations calculated as $\mathrm{TCID}_{50} \mathrm{~g}^{-1}$} \\
\hline
\end{tabular}


not be collected from 2 of the 3 dead fish in the virusexposed group. There were no significant differences in virus concentrations in gill tissues with or without $0.22 \mu \mathrm{m}$ filtration.

Several microscopic lesions were observed among both control and virus-exposed adult Chinook salmon. These included accumulations of protein suspected to be of yolk origin in the renal endothelium and hepatocytes and to be associated with a granulomatous peritonitis. Hematopoietic atrophy with vascular congestion was observed in the kidney of 2 virus-exposed fish. Also, in 2 virus-exposed fish there was marked atrophy of the intestinal submucosal eosionophilic granular leukocytes. A moderate gill hyperplasia was also observed in 2 virus-exposed fish. Vasculitis, observed in most organs, was mild to moderate in both virus-exposed and control fish, as was hepatocellular glycogen depletion.

\section{DISCUSSION AND CONCLUSIONS}

Adult Chinook salmon with no prior history of exposure to IHNV were shown to be infected by the addition of virus to the water. The resulting infections were similar to those previously described in naturally infected hatchery and wild populations of Chinook salmon. The greatest concentrations of virus were in the ovarian fluid, although the virus was evident in the gills and kidney/spleen and plasma from all exposed fish from which samples were obtained. The gills may be the initial site of virus uptake, as virus concentrations reached $10^{5} \mathrm{TCID}_{50} \mathrm{ml}^{-1}$ or more within $4 \mathrm{~d}$ p.e.; the virus may then spread from the gill, perhaps via the blood, to other tissues. However, further timecourse studies are needed to confirm this. Microscopic lesions among virus-exposed fish were not distinguishable from normal degenerative changes in unexposed fish. More detailed studies on the pathogenesis of IHNV infections in adult Chinook salmon are needed, but the nonspecific degenerative microscopic pathology observed in our study was similar to that described in another anadromous and semelparous salmonid species, the sockeye salmon (Mulcahy et al. 1982, Yamamoto et al. 1988).

Our study has demonstrated that adult Chinook salmon are susceptible to IHNV infection via waterborne exposure to moderately high levels of virus, and that infection progresses rather rapidly (4 to $14 \mathrm{~d}$ ), resulting in the release of high concentrations of virus with sexual fluids. While our exposure dose was relatively high, titers of over $10^{3} \mathrm{pfu} \mathrm{m}^{-1}$ have been detected in salmon spawning-streams (Mulcahy et al. 1983b). The most thoroughly characterized IHNV infection among adult salmon is that described among
Cedar River sockeye salmon, a naturally occurring population in Washington State (Mulcahy et al. 1982, 1983a,b, Mulcahy \& Pascho 1985, Yamamoto et al. 1988). Adult sockeye salmon entering the river have a low prevalence of infection that has allowed investigation of the sequential onset and spread of the virus over time in individual fish and in the population overall (Mulcahy \& Pascho 1985, Yamamoto et al. 1988). Movements of small groups of Cedar River sockeye adults to waters with no IHNV source have resulted in adults that remain free of virus at the time of spawning, in contrast to members of the same cohort migrating into the Cedar River, which will eventually reach a 100\% prevalence (J. Winton pers. comm.). Similarly, winterrun Chinook salmon held as captive broodstocks are found to be free of virus during routine examinations, while natural populations are known to harbor IHNV.

The presumed site of entry of the virus into adult Chinook salmon in our study was the gills. Gill tissues had concentrations of virus equal to or greater than those of the pooled kidney and spleen tissues (Table 1). Also, viral titers in the gills reached higher concentrations than in the other tissues and more rapidly. Ovarian fluids from exposed Chinook salmon had lower concentrations of virus compared to the gills of dead fish on Days 4 and 8 post-virus exposure. By 13 d, however, the ovarian fluids contained the greatest concentrations of virus detected in our study. In a time-course study of naturally infected Cedar River sockeye adults, gills were the most frequently infected organ among prespawning female sockeye salmon (e.g. no ovarian fluid expressed), followed in descending order by the spleen, lower gut, kidney and eggs, pyloric ceca, liver and brain (Mulcahy et al. 1982). No virus was detected in the serum. Among the ripe and spent females examined by Mulcahy et al. (1982), the virus was found in all organs, the serum and the ovarian fluid, although not all organs and tissues were infected in each fish. The gill, ovarian fluid, and spleen were the most prevalent locations for virus recovery, and these same tissues were found to contain IHNV in our study using a limited number of female Chinook salmon. In the sockeye salmon study, the prevalence and concentrations of virus in each organ tended to increase from prespawning to spawning (ripe) and then to spent (post-spawning) adult females. Concentrations of virus in the organs reached $10^{8} \mathrm{pfu}^{-1}$, and the highest values observed $\left(10^{9} \mathrm{pfu} \mathrm{ml}^{-1}\right)$ were in the ovarian fluid (Mulcahy et al. 1983a). The Chinook salmon in our study had comparable levels of virus in the ovarian fluid, with 2 fish containing over $10^{8} \mathrm{pfu} \mathrm{ml}^{-1}$ (Table 1).

Tissue distributions of the virus similar to those observed in our study and that of Mulcahy et al. (1982) were reported among Cedar River adult female salmon examined by Yamamoto et al. (1988). Yamamoto et al. 
(1988), also assessed fish for the presence of microscopic pathological lesions that might be attributed to IHNV. They were unable to ascribe any specific lesions to IHNV, although viral antigens were revealed by immunostaining, indicating that virus replication was occurring in numerous tissues. Yamamoto et al. (1988) concluded that IHNV-induced lesions could not be distinguished from the normal degenerative changes preceding death in these semelparous salmon. In the Chinook salmon in our study, the severe hepatocellular glycogen accumulations, presence of yolk proteins in the kidney and liver and vasculitis throughout most organs were probably changes representing degeneration prior to death of these adult salmon. A study examining a greater number of exposed and unexposed fish is needed to assess the virus-specific changes more accurately, but the observed gill hyperplasia, hematopoietic cell and eosinophilic granular leukocyte atrophy are consistent with IHNV replication in these tissues (Yasutake \& Amend 1972).

In laboratory trials, Yamamoto et al. (1988) found that adult kokanee salmon with no prior history of IHNV were highly susceptible to infection at low-tomoderate levels $\left(10^{2}\right.$ to $\left.10^{4} \mathrm{pfu} \mathrm{m} \mathrm{m}^{-1}\right)$ of virus in the water. Infection prevalence had reached $100 \%$ by $8 d$, when all exposed and unexposed fish had died of senescence. Virus concentrations reaching $10^{5} \mathrm{pfu} \mathrm{g}^{-1}$ were detected in the pooled spleen and gill tissues of exposed fish. Yamamoto et al. (1988) did not state whether virus was found in the ovarian fluids. More indepth pathogenetic studies of IHNV infection among adult Chinook salmon, including cohabitation of experimentally infected and naïve adults, are planned. However, our initial laboratory study with Chinook salmon suggests that a principal means by which IHNV prevalence increases among adult salmon upon re-entry to fresh water is infection via virus present in the water, not by reactivation of latent or persistent infection acquired as juveniles.

Acknowledgements. This research was conducted in collaboration with the US Fish and Wildlife Service and the California Department of Fish and Game under a permit from the National Marine Fisheries Service, and was supported by funds from the US Bureau of Reclamation and the California Department of Water Resources (contract 4600001540). We thank Dr. G. D. Marty for assistance with microscopic pathological examinations of adult Chinook salmon tissues. This is contribution 2195, Bodega Marine Laboratory, University of California at Davis.

\section{LITERATURE CITED}

Amend DF (1975) Detection and transmission of infectious hematopoietic necrosis virus in rainbow trout. J Wild Dis 11:471-478

Arkush KD, Bovo G, de Kinkelin P, Winton JR, Wingfield WH,
Hedrick RP (1989) Biochemical and antigenic properties of the first isolates of infectious hematopoietic necrosis virus from salmonid fish in Europe. J Aquat Anim Health 1: $148-153$

Burke J, Grischkowsky R (1984) An epizootic caused by infectious haematopoietic necrosis virus in an enhanced population of sockeye salmon, Oncorhynchus nerka (Walbaum), smolts at Hidden Creek, Alaska. J Fish Dis 7: 421-429

Busch RA (1983) Viral disease considerations in the commercial trout industry in Idaho. In: Leong JC, Braila TY (eds) Workshop on viral diseases of salmonid fishes in the Columbia River basin. Spec Publ, Bonneville Power Administration, Portland, OR, p 84-100

Bussereau F, de Kinkelin P, Le Berre M (1975) Infectivity of fish rhabdoviruses for Drosophila melanogaster. Ann Inst Pasteur Microbiol 126:389-395

Drolet BS, Chiou PP, Heidel J, Leong JC (1995) Detection of truncated virus particles in a persistent RNA virus infection in vivo. J Virol 69:2140-2147

Engelking HM, LaPatra SE, Groberg WJ Jr, Kaufman J (1994) A ten-year study of infectious hematopoietic necrosis virus vertical transmission and covert infection in chinook salmon (Oncorhynchus tshawytscha). In: Hedrick RP, Winton JR (eds) International Symposium on Aquatic Animal Health, Seattle, Washington, September. Abstr, US Fish \& Wildlife Service, Seattle, WA, p 4

Free D, Foott JS (1998) Health and physiology of broodyear 1996 Coleman National Fish Hatchery Fall chinook (Oncorhynchus tshawytscha). Rep Febr 1998, US Fish \& Wildlife Service, Anderson, CA

Healy MC (1991) The life history of the chinook salmon (Oncorhynchus tshawytscha). In: Groot C, Margolis L (eds) Pacific salmon life histories. UBC Press, Vancouver, p 311-394

Humason G (1979) Animal tissue techniques. WH Freeman, San Francisco

Kim CH, Dummer DM, Chiou PP, Leong JC (1999) Truncated particles produced in fish surviving infectious hematopoietic necrosis virus infection: mediators of persistence? J Virol 73:843-849

Kurath G, Garver KA, Troyer RM, Emmenegger EJ, EinerJensen K, Anderson ED (2003) Phylogeography of infectious hematopoietic necrosis virus in North America. J Gen Virol 84:803-814

LaPatra SE (1998) Factors affecting pathogenicity of infectious hematopoietic necrosis virus (IHNV) for salmonid fish. J Aquat Anim Health 10:121-131

LaPatra SE, Rohovec JS, Fryer JL (1989) Detection of infectious hematopoietic necrosis virus in fish mucus. Fish Pathol 24:197-202

LaPatra SE, Groberg WJ, Rohovec JS, Fryer JL (1990) Size-related susceptibility of salmonids to two strains of infectious hematopoietic necrosis virus. Trans Am Fish Soc 119:25-30

LaPatra SE, Turner T, Lauda KA, Jones GR, Walker S (1993) Characterization of the humoral response of rainbow trout to infectious hematopoietic necrosis virus. J Aquat Anim Health 5:165-171

LaPatra SE, Batts WN, Overturf K, Jones GR, Shewmaker WD, Winton JR (2001) Negligible risk associated with the movement of processed rainbow trout, Oncorhynchus mykiss (Walbaum), from an infectious hematopoietic necrosis virus (IHNV) endemic area. J Fish Dis 24:399-408

Mulcahy D, Pascho RJ (1985) Vertical transmission of infectious hematopoietic necrosis virus in sockeye salmon, Oncorhynchus nerka (Walbaum): isolation of virus from dead eggs and fry. J Fis Dis 8:393-396 
Mulcahy D, Burke J, Pascho R, Jenes CK (1982) Pathogenesis of infectious hematopoietic necrosis virus in adult sockeye salmon (Oncorhynchus nerka). Can J Fish Aquat Sci 39: 1144-1149

Mulcahy D, Pascho RJ, Jenes CK (1983a) Titre distribution patterns of infectious haematopoietic necrosis virus in ovarian fluids of hatchery and feral salmon populations. $\mathrm{J}$ Fis Dis 6:183-188

Mulcahy D, Pascho RJ, Jenes CK (1983b) Detection of infectious haematopoietic necrosis virus in river water and demonstration of waterborne transmission. J Fis Dis 6: 321-330

Parisot TJ, Pelnar J (1962) An interim report on Sacramento River chinook disease: a viruslike disease of chinook salmon. Prog Fish-Cult Apr:51-55

Pilcher KS, Fryer JL (1980) The viral diseases of fish: a review through 1978. Part I: Diseases of proven etiology. Crit Rev Microbiol 7:287-364

Ross AJ, Pelnar J, Rucker RR (1960) A virus-like disease of chinook salmon. Trans Am Fish Soc 89:160-163

Scott JL, Fendrick JL, Leong JC (1980) Growth of infectious hematopoietic necrosis virus in mosquito and fish cell lines. Wasmann J Biol 38:21-29

St-Hilaire S, Ribble C, Traxler G, Davies T, Kent ML (2001) Evidence for a carrier state of infectious hematopoietic necrosis virus in chinook salmon Oncorhynchus tshawytscha. Dis Aquat Org 46:173-179

Editorial responsibility: Jo-Ann Leong,

Kaneohe, Hawaii, USA
Thoesen JC (1994) Suggested procedures for the detection and identification of certain finfish and shellfish pathogens, 4th edn, Version 1. Fish Health Section, American Fisheries Society, Bethesda, MD

Traxler GS (1986) An epizootic of infectious haematopoietic necrosis virus in 2-year-old kokanee, Oncorhynchus nerka (Walbaum) at Lake Cowichan, British Columbia. J Fish Dis 9:545-549

Williams IV, Amend DF (1976) A natural epizootic of infectious hematopoietic necrosis in fry of sockeye salmon (Oncorhynchus nerka) at Chilko Lake, British Columbia. J Fish Res Board Can 33:1564-1567

Wingfield WH, Chan LD (1970) Studies on the Sacramento River chinook disease and its causative agent. In: Snieszko SF (ed) A symposium on diseases of fish and shellfish. American Fisheries Society, Washington, DC, p 307-318

Wolf K (1988) Fish viruses and fish viral diseases. Cornell University Press, Ithaca

Yamamoto T, Arakawa CK, Batts WN, Winton JR (1988) Comparison of infectious hematopoietic necrosis in natural and experimental infections of spawning salmonids by infectivity and immunohistochemistry. In: Ahne W, Kurstak E (eds) Viruses of lower vertebrates. Springer-Verlag, Heidelberg, p 411-429

Yasutake WT, Amend DF (1972) Some aspects of pathogenesis of infectious hematopoietic necrosis (IHN). J Fish Biol $4: 261-264$

Submitted: March 17, 2003; Accepted: October 21, 2003

Proofs received from author(s): May 12, 2004 